\title{
Ethnic Identity: Narratives of a Quilombola Community in a Video Documentary
}

\section{Cledineia Carvalho Santos}

Milton Santos Institute of Humanities, Arts and Sciences, Federal University of Bahia, Salvador, Brazil

\author{
Email address: \\ keucarvalho@yahoo.com.br
}

\section{To cite this article:}

Cledineia Carvalho Santos. Ethnic Identity: Narratives of a Quilombola Community in a Video Documentary. International Journal of Science, Technology and Society. Vol. 7, No. 6, 2019, pp. 100-106. doi: 10.11648/j.ijsts.20190706.14

Received: July 20, 2019; Accepted: October 20, 2019; Published: December 9, 2019

\begin{abstract}
Ethnic identity has been a much debated theme in the social and human sciences, because it is inherent in the study of human groups around the world. Thus, this article presents a brief analysis of the film narrative elaborated by the Quilombola community New hope of remnants, Located in the municipality of Wenceslau Guimarães (Bahia, Brasil), cujas histórias permeiam a construção da identidade étnica em documentários em vídeo produzidos pelos próprios moradores em sua busca de reconhecimento, com vistas à obtenção de direitos garantidos pelo Estado. The article targets both the narrative elements and the political dimension that involves ethnic recognition within the scope of identity and belonging. We use video documentary film analysis as a method in the light of theorists who focus on discussing Ethnic Identity, Culture, and Communication. Throughout the analysis it is possible to understand the strategies elaborated by the authors of the video documentary, technical weaknesses and lack of neutrality in the elaboration of the script. It was possible to conclude that in making the documentary the community enhances or suppresses their ethnic identities, as well as defines boundaries between who is or is not descended from the founding ancestors to enhance the local culture, as inheritance and belonging. The video documentary, although amateur, is original and achieves the goal intended by the community under study. The present study is therefore relevant for other peoples with similar processes to be inspired by the search for local visibility.
\end{abstract}

Keywords: Ethnic Identity, Narrative, Communication

\section{Introduction}

The current text is the result of a study of the production of a video documentary titled "História da Fundação de Nova Esperança" (History of the Founding of Nova Esperança) elaborated by community members in 2008. The documentary sought to register older residents' narratives about the history of the community's founding in order to serve as a reference for the recognition of the community as a site of remanescentes quilombolas ${ }^{1}$. Since the video was produced by the subjects themselves and is therefore situated outside privileged models of communication production, it is relevant because it makes previously subjugated subjects visible. Narratives throughout the video documentary enunciate subjects' ethnic identities in a collective construct

1 Remanescentes quilombolas refers to a community of descendants of black people who had escaped from slavery and formed a quilombo. An analogous term in English is "maroon". of their history.

This text constitutes a media culture study of an original work produced by "common" subjects. The guiding idea is centered on self-affirmation and self-recognition as remanescentes quilombolas, to which end they voice histories that extol their ancestors in a weaving of ethnic identity.

Communication, by means of various available tools and techniques, plays an important role in the promotion and spread of information about subaltern and historically silenced groups who decide to speak for themselves without intermediaries, overcoming the subaltern condition, constructing their autonomy in resonance with Beatriz Nascimento's affirmation that "It is time for us to talk about our ourselves neither as 'contributors' nor as victims of a social history formation, but rather as participants in that formation" [1].

Because of this, analyzing a video produced without market-related intentions, but which has sociopolitical value, 
contributes to our thinking about how media products can serve to promote rights and freedom and involve the possibility of intellectual production in the subaltern's own voice.

Quilombola communities are important historic and discursive narrators. Therefore, the use of communication as an instrument in the fight for recognition allows them to articulate dialogues in their struggle for essential rights such as identity, territory and being quilombola.

The residents of the Community of remanescentes quilombolas of Nova Esperança organize themselves around the identities outlined in their discourses. And in order to talk about themselves, they make use of possible media strategies.

In view of the above, the idea of making this documentary, with the theme "History of the New Hope Foundation", has emerged, Focusing mainly on the stories of the founding ancestors and how they established themselves as remaining subjects of the quilombos.

Thus, in order to address its proposed objective, this text will make use of theories that discuss Ethnic identity, Culture, Communication and Film Analysis. Among these, we highlight: Rudimar BALDISSERA (2009 e 2010); Fredrik BARTH (1998); Roy WAGNER (2010); and David BORDWELL (1991); Stuart HALL (2003); HALBWACH (2004). In constructing the research, I use film analysis, bibliographic research, narrative method and oral history techniques.

The Remanescentes Quilombolas Community Nova Esperança

Nova Esperança is a community of remanescentes de quilombos located in the municipality of Wenceslau Guimarães, Bahia, Brazil, at $290 \mathrm{~km}$ from the state's capital, Salvador. It has an estimated population of 3000 inhabitants spread between the community's center and its surrounding territory. There are 100 family nuclei at the heart of the community. In terms of gender, there are approximately $42 \%$ men and $58 \%$ women. The quilombolas live off the cultivation of cocoa, banana and graviola (soursop), all produced on a commercial scale. In parallel there is also subsistence production of corn, manioc, oranges, beans and the rearing of small animals for consumption by the community.

The existing labor relations take place between landowners and people who provide services, so-called diaristas (dayworkers). There are also sporadic labor ecxhanges called $d^{\prime} m \tilde{a} o^{2}$.

Another common work relation is that of meeiros ${ }^{3}$, which consists of an exchange between the owner of the land or plantation and the person who does farming labor. In this type of work, there is an equal division of profits.

Community living is established through kinship or companionship ties, which contributes to peaceful relations among residents. Another preponderant factor is the fight for

$2 D^{\prime}$ mão refers to a collective work event, similar to mutirão.

3 In Portuguese, the term meeiro contains the word "half", and implies a fiftyfifty division of profits. "Sharecropper" is one possible, though incomplete, translation of the term. recognition of the community as a site of black ancestry. As such, community members tell and interlace stories of their common ancestors.

Like all quilombos communities in Brazil, this territory of identity values cultural traits, ethnic belonging, and collective relations. The word "quilombo", of Bantu origin, means warrior camp in the forest [2] In Brazil, the term quilombo was used to refer to the mutual support units created by the rebels against the slave system and their reactions, organizations and struggles to end slavery in the country [2].

The quilombo concept has been extended to cover as many

Afro-descendants as possible, not necessarily the result of a place of movements of ruptures to slavery, but to other groups of people who somehow have ties with this period and sought to consolidate themselves into a territory with its own identities and cultural representations The aim has been to take into account the specificity of each remaining community studied, as well as its identity, its selfrepresentation, its history and the bonds established by the social subjects in the present. Quilombo has therefore been understood as a land of blacks, as a space of resistance, in the various ways through which this resistance can manifest itself [3].

Quilombola law permeates the interconnected cultural heritage between the material and the immaterial. For this reason, the narratives of the subjects inserted in the context of the self-attribution of both historical, territorial or cultural relations place the "remnant quilombolas" in a continuous relationship between their historical past and their present political struggle.

The community of Nova Esperança is characterized by identity traits that connect the present to an oppressive past. The community differentiates itself from others around it based on those who are considered to be inside and outside of the identity construct. In that way, they point out the limit between 'Them' and 'Others' through which they delimit ethnic boundaries.

\section{Theoretical Foundation}

Video documentaries have become an object of reflection for many theorists due to being an important medium through which facts are reconstructed, ideas are announced and forgotten histories are brought back into memory. Documentaries are capable of transforming intangible things into visible realities. That is why video documentaries are important with regards to the histories of historically subaltern traditional communities, such as in the case of this article's object of analysis.

However, it is not as simple as one might imagine defining the video documentary as a genre. This is because its content is supposed to be an account of reality, a collection of stories and information to be validated by those who watch it. In that way it is "a narrative with camera images that establishes assertions about the world, to the degree that there is a spectator who receives that narrative as an assertion about the world" [4]. In other words, it is not enough for one to say that 
the documentary is a film of reality, since it must be accepted and validated.

As the documentary support used to deal with social issues, it is necessary to recognize the relevance that its production had in the process of recognition of the community as quilombola remnants, expanding the access networks about its history, Bill Nicholls, author of the book "Introduction to Documentary" refers to a social representation reported in documentary as a way to enable new understandings of the common world.

Starting from the principle that the classic function of a documentary filmmaker is to inform and bring reflections about the world to the spectator, the video being analyzed here fulfills the role of informing and fostering the stories it tells, given that the intent of its producers was to establish a representation of the locale's identity.

The "New Hope Story" video documentary features participation from everyone involved, from the scriptwriting process to the interviews resulting in a participatory documentary.

The participatory mode, as its name suggests, is marked by showing the participation of the documentary filmmaker and his team. Thus, it becomes an active subject in the recording/filming process, as it appears in conversation with the team and causes the interviewee to speak [5].

The video documentary must have meaning in terms of what it is meant to say, for "if someone - another - gives meaning to something and assumes it as communication, then it is communication" [6]. The video documentary is subject to interpretation, moving beyond the formal production environment and into other forms of production.

In this respect, David Bordwell says "In following a narrative, we make assumptions and draw on schemata and routines in order to arrive at conclusions about the world of the story. Somehow all this may come out as pleasure, but we scarcely know how" [7]

In that sense, the subject's story and the context in which the film is produced transforms its signification process.

"The documentary is seen as a traditional field, with rules to be followed. Moving beyond those boundaries attests to inventiveness and creativity" [4]. And indeed, the documentary produced by the residents of Nova Esperança can be characterized in such a way.

In this case, communicational organization moves beyond privileged production space to manifest itself in different places and legitimating contexts of a final product. The truth exists through what is said, since "if somebody - an other attributes sense to something and assumes it as communication, then it is communication" [6]

The narratives present in the documentary about the history of the Nova Esperança community express subjectivities in a representative tone with the intent of convincing the viewer of what community members desire to say and making an imprint as authentic history, with a connotation of ethnic identity.

The narratives of the documentary feed on the memory of its residents and, at the same time enhancing or suppressing what the memory reaches or selects.

The narratives of the documentary feed on the memory of its residents while at the same time enhancing or suppressing what the memory achieves or selects. The places of memory are, first and foremost, remains. [...] They are the rituals of a society without ritual; fleeting sacralizations in a society that desecrates; particular loyalties of a society that flattens particularisms; effective differentiations in a society that levels out by principle; signs of group recognition and belonging in a society that only tends to recognize equal and identical individuals [8].

For Pierre Nora we live faster and faster, which in a way makes the death of the past possible, as something nonexistent, crumbling the memory. This contributes to the search for traditional communities to look for ways to remember this past and record in documentary. That way history can be saved for generations to come.

In this sense we seek to create archives of spontaneous memory and thus retain the past: "If what they defend was not threatened, there would be no need to build them. If we truly lived the memories that surround them, they would be useless" [8].

As traditional memory disappears, we feel compelled to religiously accumulate traces, testimonies, documents, images, speeches, visible signs of what it was, as if this increasingly prolific dossier should become evidence in which court of history is unknown [8].

Memorialist narratives seek a retrospective look, from a lived or heard past that somehow feeds the lived reality. However, this recollection is often aimed much more at enhancing this past to corroborate the identity in which "the real can be mythologized as much as the mythic can engender strong effects of reality" [9]

Memory in this sense is selective, sometimes aiming to bring collectivity, sometimes individuality in a contract between what is the self and others in the construction of memories, whether or not this collective solves these memories.

For Maurice Halbawachs:

For our memory to benefit from others, it is not enough for us to bring their testimonies to us; It must also be that she has not failed to agree with her memories and that there are sufficient points of contact between her and the others so that the memory that others bring us can be reconstructed on a common basis [10].

Collective memory tends to define and reinforce feelings of belonging and social boundaries between collectivities, especially in traditional communities.

Regarding the identity highlighted by the community in the documentary, we understand them as a social and political dimension. Social to which their relations between members woven in daily life and politics regarding the search for rights based on characteristics that unite them.

Thus, each subject within the community or a given social, historical or political context contributes to the maintenance of the identity of this group, constituting ethnicities. All subjects are actors of a cultural and identity plot. 
Barth, Poutignat \& Streiff-Fenart [11] explain that:

Because of this disjunction between culture and ethnicity, it is generally assumed that the degree to which ethnic identities are rooted in earlier cultural realities is highly variable, and that all "ethnic" culture is to some extent "patch". Ethnicity is not empty of cultural content [...] but it is never simply the expression of a ready-made culture. It always implies a process of selecting cultural traits that actors take to transform them into criteria of consignment or identification with an ethnic group [11].

Identity occupies an emerging place in which the subject relies on himself to situate himself ethnically. They are therefore intertwined in the conceptions of self in relations with others. "... ethnic identities only mobilize with reference to an otherness, and ethnicity always implies the organization of dichotomous groupings between the We/Them..." [12].

The identity of a group is formed through the absorption of different cultural traits, in a dynamic way that is in constant reconstruction. Studies take hybridization processes into consideration and take into account that identities are mobile, with differences being delineated through negotiations and the construction of meanings, "all terms of identity depend on the establishing of limits - defining what they are in relation to what they are not" [13]. Belonging to an ethnic group is a question "of social definition, of interaction between members' self-definition and the exogenous and endogenous definition of ethnic belonging that transforms ethnicity into a dynamic process always subject to redefinition and recomposition" [11]. In this sense, interpersonal and identity relations of the group re-elaborate ethnic belonging.

The concept of identity proposed here is to think of its social and historical-philosophical conjectures to the detriment of changes and social connections with each other. That is, Identity is flexible and continuous, being built by certain groups or individuals by the need for survival and fluidity of relationships and lived context. Thus, "The current tendency is to conceive of it as a logical and ontological synthesis, in whose constitution social relations occupy a prominent place" [14].

For Bauman Identity is liquid, changing throughout life, as it is negotiable relationships. Like this:

[...] 'identity' is only revealed to us as something to be invented, not discovered; as the target of an effort, a goal; as something that still needs to be built from scratch or to choose between alternatives and then fight for it and protect it by fighting even more - even if, for this fight to be victorious, the truth about the precarious and eternally unfinished condition of deva be, and tends to be, suppressed and laboriously concealed" [15].

Another factor that contributes to the reconstruction of identity is the feeling of belonging to a given culture defined as an "unconscious process" [13] formed by relationships with the cultural traits of other groups.

Identity is, therefore, an unending process of interactions between people resulting in boundaries and proximities in a cultural territory. In other words, we construct identities in interaction with the other - in contact with family, community, culture, in various spaces - in a way that leads us to acquire information that results in subjectivities. As Roy Wagner tells us, man "is a mediator of things, a builder, and is capable of turning himself into the things around him, integrating them into his knowledge, action and being" [16].

As an identity, culture is dynamically acquired and always reinvented and resignified, capable of changing at any time in communication with others. In these terms "the effect of this invention is as profound as it is unconscious; the object is created in the act of trying to represent it more objectively, and at the same time (by analogical extension) the ideas and forms are created through which the invention of the object takes place" [16].

In this sense, culture is constituted by a metaphoric means in which webs of meanings are imprinted on the inventive logic of a given group, which acts in a game of interests, symbolizing the conventional and inevitable of human beings, whether as individuals or groups.

\section{Weaving Ethnic Identities in the Video Documentary}

Narrating, a human and collective act. Narrative would have no meaning if it were not for the listening and interacting other. Therefore, narration is also a collective act," (...) it is humanity in movement. Looks allow heterogeneous times. It is history under construction. Memories that speak" [16].

Although in contemporary times narratives are mobile and ephemeral, it is evident that oral forms still occupy a privileged role in the maintenance of history. In this sense, using resources to store collective memory becomes relevant for the permanence of text.

For Hallbwachs, memory is something lived, experienced operated in the community and narrated from the perspective of human experience, so it is not neutral [10].

In this sense:

How to get a memorized "pure fact" from the ocean floor of ages? When we pull the network we will see how much it comes loaded with ideological representations. More than the unilinear document, the narrative shows the complexity of the event. It is the privileged way to reach the point of articulation of history with everyday life. Gathering diverse, sometimes opposing, views is a constant recomposition of data [17].

Based on this premise, the community of quilombola remnants of Nova Esperança translated into the video documentary the goal of making the history of their ancestors a text for posterity, giving meaning to what they intend to say. To make this a reality, they made a narrative video in which they sought to re-elaborate the trajectory of the community founder, Mr. Faustino dos Santos and his family.

The video documentary "História de Nova Esperança" has a duration of 28 minutes. A narrator-character conducts the story in order to tell the story of the Founders of the community and in that way justify the quilombola origins of the group to the Fundação Palmares (Palmares Foundation) ${ }^{4}$.

4 Fundação Cultural Palmares (FCP), the Palmares Cultural Foundation, is an 
Before the video's production, there was a dialogic process between the interlocutors of the Fundação Palmares and the residents of Nova Esperança, which led the residents to define themselves as remanescentes quilombolas. After this happened, they initiated the process of Official recognition. It was only then that they decided to weave the stories of their ancestors told in the video.

The video is simple in its presentation, which indicates that its producers did not have commercial or cinematographic intentions. In other words, its only purpose was the affirmation as remanescentes quilombolas, since "ethnic belonging is, at the same time, a question of origin" [12].

The organizational paradigm used in the documentary is not complex. The documentary does not worry itself with aesthetics or technical aspects, since its intention is solely that of making its narrated history into truth in order to acquire the coveted recognition. Along with sociopolitical advantages, gaining certification also means documenting and exalting one's historic past in a process of construction of meaning.

Afterwards, the product was transformed into pedagogic material for the local school with the intent of making the memory "eternal". The video was produced under the understanding that the image is the best way to present what one wants to say, since it can reach many people and create new ways of looking at the community's people.

In the documentary, collaborators' narratives come together in a common space which, according to them, is marked by the arrival of the founder, Mr. Faustino dos Santos and his family, around the first half of the twentieth century.

The video documentary addresses the historic and ancestral relations of the community's residents in an ethnic perspective. This is evident at the beginning of the documentary when Senhorinha dos Santos says that "Faustino was not a child, lived as a slave harvesting sugar cane" [18]. In this account we realize how important it is, the highlight of the origins of belonging, to relate the conditions in which the precursor lived before reaching the community.

By bringing to light memories, explanations, memories, narrators shape the video documentary into a product of communication, making the story possible to be seen and understood. Although we are living the time of technological advances, the way of telling and transmitting memory and orality remain the contribution to the witness of history and of what essentially human experience.

Another section of the documentary names the seven children $^{5}$ who would later come to inhabit the locale, leading

entity connected to Brazil's Ministry of Culture (MinC). It is the first public institution geared towards the promotion and preservation of Afro-Brazilian art and culture. So far, FCP has emitted more than 2476 certifications for quilombola communities. The document recognizes these communities' rights and provides access to the Federal Government's social programs. FCP is of note for its promotion, fostering and preservation of black cultural manifestations and its support and propagation of the Law 10.639/03, which makes it mandatory for schools to teach African and Afro-Brazilian history. The Palmares Foundation has distributed publications that discuss and promote the preservation of AfroBrazilian culture and support teachers and schools in the application of the Law.

5 Maurício, Marcelina, Salvador, Roque, João, Feliciana and Amadeu to the creation of the community. As the narrator indicates, "The children went along getting married and constructing their houses as well" [18].

Another highlight pointed out by the narrator is about the odyssey that Faustino dos Santos passed through before arriving in the locale: "Because of the drought they were forced to move, with surracas on their backs, making their way through the dust along the road... upon arriving, Faustino breathed in relief and chose the name New Hope (Nova Esperança)" [18].

In this clip, we perceive the common intentions and objectives involved in the "truths" they seek to announce in affirming the group's identity as quilombola descendants. In this sense, the "(...) idea of organization also, and fundamentally, involves subjects in relation, laboring for specific, clear, defined objectives" [19].

In the context of a past of struggle for fixity, the constituted symbolic universe makes it possible for us to delineate an ideological logic of subjects in interaction which at once unifies and differentiates them, influencing the construction of local ethnic identity. This is noticeable when the narrator explains that "The couple's second daughter, named Marcelina, became a midwife, the family's benzedeira, and gave homemade remedies to the children, since there was no doctor (...)" [18].

This account seeks to show the "trails" of the community's culture, the connections with African knowledges. In that way, the video intends to make truth out of ancestral connections with an enslaved past, seeking recognition because ethnic identity is based on the notion of the self within a context.

In that way, the identity traced out in the community's narrative is structured in intersectional relations, "in which (...) they try to construct a life in common, at the same time as they retain an aspect of their 'original' identity" [13] constructed in an individual history.

On narrating the odyssey of their ancestors, the narrators interlace shared histories while excluding others, in an ethnic identity construct. This makes the video exceedingly important from the post-modern point of view proposed by [13] in which identity makes a "people" ever more unified within a community in an ongoing formation process. In this sense, [13] refers to Identity as a "mobile celebration".

Identity is not inherent upon birth. On the contrary, it is constructed throughout our existence through relations which are constructed and individualized by narratives of the self and continuously elaborated in the present as the subject weaves meanings in hybrid perspectives in the communities in which they live.

Identity is said to occur in a continuous process of interaction and differences, where boundaries are located and constituted between quilombo remnants and other residents.

Identity is, therefore, an unending process of interactions between people resulting in boundaries and proximities in a cultural territory. In other words, we construct identities in interaction with the other - in contact with the family, the community, the culture, in various spaces - in a way that we 
acquire information resulting in subjectivities produced in a process of self-identification.

The Identity of resistance is created by social actors who are disadvantaged and stigmatized by the logic of domination, creating barriers to their survival based on different principles from those that guide social institutions. Project Identity is built from cultural materials to redefine positions in society, thus transforming the social structure [20].

In the narratives constructed in the video, the community recognizes itself as black and therefore as descendants of enslaved peoples. In the interim period, they remember the stories of their grandparents, from captivity to the new land, highlighting the history of the family founded on ethnic, racial and cultural traits.

\section{Results}

The results of the analysis of the video documentary show that the stories narrated in the video produce well demarcated boundaries between descendants and other residents, delineating [12] refers to as ethnic boundaries.

Given that ethnic identity is a perception of the self as a group within a given situation, the narratives registered in the analyzed video documentary represent the community of Nova Esperança as being in a process of identity reconstruction that is typical of quilombola communities, since they are affirming themselves as a group that is different from others in the territory around them, implicated in ethnicity connected to the slavery period.

The elements that constitute the ethnic identities outlined in the video narratives situate the descendants of the founders as protagonists of local history, minimizing other existing stories. It is emphasized that "to the extent that authors use ethnic identities to characterize themselves and others, they form ethnic groups..." [12]. In this context, ethnicity emerges as categories are created to identify who belongs and does not belong to the group, thus establishing ethnic boundaries.

With the video's narrative, the community's remanescentes de quilombo select characteristics to recuperate traits of the identity which directly connects them to a past of enslavement. The community differentiates itself from others around it in order to say who does and does not belong to that group. Ethnic belonging is limited in terms of insiders and outsiders.

The narrator traces the history of the precursors, putting into action different criteria for this affirmation of identity such as: kinship ties, racial phenotype, economic situation and reminders of a past enslavement. These descriptions are indispensable to social identity and ethnic belonging.

\section{Discussion}

Discussion of resultsStarting from a communicational analytical approach, the present article sought to understand how the residents of the Quilombola Nova Esperança Community, located in the rural area of Wenceslau
Guimarães, a city in the Low South region of the state of Bahia, Brazil, showed through the production of a video the history of the place, while praising the founding ancestors as a substantial element for the intended recognition. In narrating, residents relive facts, enhance individual and collective memory, and establish ethnic boundaries between descendants and non-descendants of the community's founders.

[...] individual memory exists, but it is rooted in different contexts that simultaneity or contingency approaches for a moment. Remembrance is situated at the crossroads of the multiple solidarity networks in which we are involved. Nothing escapes the synchronic plot of current social existence, it is from the combination of these various elements that can emerge that form we call remembrance, because we translate it into a language [10].

It is in orality that the narratives gain form and meaning, transmitting the lived to the collective understanding. Thus, collective and individual memories interconnect, resulting in the strengthening of group identity.

Despite the use of technology to record and show the story, the defining element of the video documentary is orality. The whole video is narrated, which makes the video quite understandable to the local people.

By narrating the story and presenting images of the times of the founders' arrival in the background, associated with the memory, the documentary ensures evidence of fidelity of the facts.

The filming and script is amateur, but with a dense content to the intended purpose, gathering information that proved that this community is a place of remnant quilombolas.

In revisiting the narrative of the video documentary, in the light of the theoretical framework supported here, it can be said that much has been said and so many forgotten, silenced, omitted. The boundaries between family and non-family members are an intriguing element, so other subjects have other narratives that can enrich their own story.

In the meantime, the narrative is the support for the end result of the product. It is her responsibility to materialize and gives shape and voice to memory.

\section{Conclusion}

In summary, the results show that the community uses communication as a strategy for its visibility towards the other. The construction based on the video documentary aims to give visibility to the collective identity of the group, whose purpose seems to be to be seen in a positive perspective on the quilombola being with highlights to their ethnic identities. The documentary can serve as a guiding thread for future studies regarding the history of the quilombo.

\section{Recommendation}

Regarding the production of film material, it is suggested that there are studies that approach the theme in depth, investigating not only its script, but also its finalization, 
musicality and photography.

We suggest that studies on the ways of producing knowledge of traditional peoples, including those with access to new technologies, be the object of study and dissemination of this knowledge from the perspective of Decolonial studies.

Finally, I understand that in the social sciences we will never be aware of everything involving an object, we point out that the article presents many other possibilities for discussion and that should be discussed and appropriated by other researchers.

\section{References}

[1] RATTS, Alex. Eu sou atlântica: sobre a trajetória de vida de Beatriz Nascimento. Instituto Kuanza; Imprensa Oficial: São Paulo, 2006.

[2] LEITE, Ilka Boaventura. O projeto político quilombola: desafios, conquistas e impasses atuais. Revista Estudos Feministas, v. 16, n. 3, p. 965-977, 2008. Disponível em $<$ http://www.scielo.br/pdf/ref/v16n3/15.pdf $>$. Acesso em: 11 maio 2015.

[3] FIABANI. Aldemir. Mato, palhoça e pilão: o quilombo, da escravidão às comunidades remanescentes (1532-2004). Editora Expressão Popular, 2005.

[4] RAMOS, F. P. Mas Afinal. o que é Mesmo Documentário? Editora Senac, São Paulo, 2008.

[5] NICHOLS, B. Introdução ao documentário. Campinas: Papirus, 2005 ( $5^{\text {a }}$ Ed. 2010).

[6] BALDISSERA, Rudimar. Comunicação Organizacional na perspectiva da complexidade Organizational. Ano 6. Edição Especial. 2009.

[7] BORDWELL, D. Making Meaning: Inference and Rhetoric in the Interpretation of Cinema. Cambridge: Harvard University Press, 1991.

[8] NORA, Pierre. Entre memória e história: a problemática dos lugares. Projeto História, São Paulo, n. 10.1993.
[9] HUYSSEN, Andreas. Seduzidos pela memória: arquitetura, monumentos, mídia. Rio: Aeroplano, 2000.

[10] HALBWACHS, Maurice. A memória coletiva. São Paulo: Centauro, 2004.

[11] POUTIGNAT, Philippe; STREIFF_FENART, Jocelyne. Teorias da Etnicidade. Seguido de Grupos Étnicos e suas fronteiras de Fredrik Barth. Tradução de Elcio Fernandes. $2^{\mathrm{a}}$ ed. - São Paulo: Ed. Unesp, 2011.

[12] BARTH. Fredrik. Grupos Étnicos e suas fronteiras. Tradução de Elcio Fernandes. $2^{\mathrm{a}}$ ed. - São Paulo: Ed. Unesp, 2011.

[13] HALL, Stuart. A identidade Cultural na pós-modernidade. 7. Ed. Rio de Janeiro: DP \& A, 2003.

[14] JACQUES, M. da G. C. Identidade e trabalho. In: CATTANI; A. D.; HOLZMANN, L. Dicionário de trabalho e tecnologia. Porto Alegre: Ed. da UFRGS, 2006.

[15] BAUMAN, Z. Identidade. Entrevista a Benedetto Vecchi. Rio de Janeiro: J. Zahar, 2005.

[16] DELGADO, L. de A. N. História oral: memória, tempo e identidades. Belo Horizonte: Autêntica, 2006. Col. Leitura, escrita e oralidade.

[17] BOSI, Ecléa. O tempo vivo da memória: ensaios de psicologia social. 2 ed. São Paulo: Ateliê Editorial, 2004.

[18] NOVA ESPERANÇA. História de. Vídeo-documentário. Roteiro e finalização: Renan dos Santos, Produção coletiva. Wenceslau Guimarães, Bahia, Brasil. 28 min. 2008.

[19] BALDISSERA, Rudimar. Organizações como complexus de diálogos, subjetividade e significação. In. KUNSCH, M. M. K (org). A comunicação como fator de humanização das organizações. São Paulo, SP. Difusão Editora, 2010.

[20] WAGNER, Roy. A invenção da cultura. Trad. Marcela Coelho de Souza e Alexandre Morales. São Paulo: Cosac Naify, 2010.

[21] CASTELlS, M. O poder da identidade. 6. ed. São Paulo: Paz e Terra, 2008. Publicado originalmente em 1942. 